\title{
Copenhagen Burnout Inventory - Student Version: Adaptation and Transcultural Validation for Portugal and Brazil
}

\author{
Inventário de Burnout de Copenhagen - Versão Estudantes: Adaptação \\ e Validação Transcultural para Portugal e Brasil
}

\author{
Juliana Alvares Duarte Bonini Campos ${ }^{*}, a$, Mary Sandra Carlotto ${ }^{b}$ \& João Marôco ${ }^{c}$ \\ ${ }^{a}$ Universidade Estadual Paulista Julio de Mesquita Filho, Araraquara, Brasil, \\ ${ }^{b}$ Universidade Luterana do Brasil, Canoas, Brasil \\ \& Instituto Superior de Psicologia Aplicada, Lisboa, Portugal
}

\begin{abstract}
The Copenhagen Burnout Inventory for college students (CBI-S) was adapted to the Portuguese language and its reliability and validity studied in a sample of both Brazilian $(n=958)$ and Portuguese $(n=556)$ college students. The confirmatory factor analysis of the CBI-S showed good fit but two items were removed since they lack individual reliability $(\lambda<.50)$. The new structure showed a good fit on $2 / 3$ of the total sample and was invariant in the other $1 / 3$ of the sample. The CBI-S factor weights were not invariant in the Brazilian and Portuguese samples. Internal consistency as well as convergent, discriminant and concurrent validity were good. The Portuguese CBI-S showed adequate reliability and validity but did not show cross-cultural validity.

Keywords: Burnout, college students, evaluation, Psychometrics.

Resumo

Realizou-se adaptação cultural do Inventário de Burnout de Copenhagen para estudantes (CBI-S) em português e estimou-se sua confiabilidade e validade. O CBI-S foi preenchido por 958 estudantes universitários brasileiros e 556 portugueses. O modelo fatorial original apresentou bom ajustamento entretanto, foram removidos dois itens com confiabilidade individual baixa $(\lambda<0,5)$. A nova estrutura apresentou bom ajustamento a $2 / 3$ da amostra total sendo invariante no $1 / 3$ restante da amostra original. Verficou-se adequada consistência interna e validade convergente, discriminante e concorrente. Os pesos fatoriais do CBI-S não foram invariantes nas amostras de Brasil e Portugal. O CBI-S apresentou adequada confiabilidade e validade entretanto, verificou-se ausência de estabilidade transcultural.

Palavras-chave: Burnout, estudantes universitários, avaliação, Psicometria.
\end{abstract}

The burnout syndrome is a chronic condition characterized by a state of complete depletion of individual energy, associated with an intense frustration with work activities (Maslach, Schaufeli, \& Leiter, 2001). The instrument most commonly used to identify the burnout syndrome is the Maslach Burnout Inventory (MBI; Maslach \& Jackson, 1981), which has currently four different versions aimed at: the general population (MBI-GS), professionals with large human involvement (MBI-HSS), teachers (MBIES), and students (MBI-SS; Schaufeli, Leiter, \& Maslach,

*Endereço para correspondência: Departamento de Odontologia Social, Faculdade de Odontologia de Araraquara, Universidade Estadual Paulista, Rua Humaitá, 1680, Centro, Araraquara, SP, Brasil 14801903. Tel.: (16) 33016358 ou (16) 33016343. E-mail: jucampos@foar.unesp.br

Acknowledgements: We would like to thank the Foundation for Support to Research of the State of São Paulo (FAPESP) for the financial support (processes: 2010/15062-3 e 2010/09295-5).
2009). Although various versions of the MBI have been proposed in order to improve the detection of Burnout in different population groups, several authors have pointed out theoretical and methodological flaws in the design of the MBI, which may compromise the results when the instrument is used in different populations from the one it was originally developed (Demerouti, Bakker, Nachreiner, \& Schaufeli, 2001; Kristensen, Borritz, Villadsen, \& Christensen, 2005).

Garden (1987) and Milfont, Denny, Ameratunga, Robinson and Merry (2008) highlight the difficulties of using the MBI in populations that do not have an important human involvement in their work activities or that belong to other cultures. Doty e Glick (1998) and Milfont et al. (2008) criticize the fact that the three subscales, proposed in the instrument, do not have the items formulated in the same direction, which was also pointed out by Demerouti et al. (2001) and Demerouti, Bakker, Vardakou and Kantas (2003). These authors also add as limitations of the MBI the fact that the Exhaustion dimension only 
considers the emotional aspects, not including the physical and cognitive aspects. Kristensen et al. (2005) and Yeh, Cheng, Chen, Hu and Kristensen (2007) consider that Exhaustion is the central aspect of the syndrome, and that the MBI by considering Depersonalization and Professional Effectiveness dimensions is mischaracterizing the concept of Burnout, given that these dimensions represent, respectively, a coping strategy and a consequence of the syndrome.

Thus, new instruments, namely the Copenhagen Inventory (CBI) proposed by Kristensen et al. (2005) was formulated considering the Fatigue and/or Exhaustion as a central construct. The CBI consists of 19 questions divided into three factors "personal burnout ", "workrelated burnout" and "client related burnout". However, the authors state that the expressions used in the instrument's questions and/or factors can be freely adapted to any professional class.

Among populations identified as at risk for the development of burnout syndrome we can find college students (Carlotto, Nakamura, \& Camara, 2006; Marôco, Tecedeiro, Martins, \& Meireles, 2008; Martinez, Pinto, \& Silva, 2000; Schaufeli, Martinez, Pinto, Salanova, \& Bakker, 2002). Balogun, Helgemoe, Pellegrini and Hoeberlein (1995) argue that the competitive environment found among students, teachers and supervisors, leads to conflicts that can lead to stress and emotional exhaustion. Another problem pointed out by NogueiraMartins (2001) is the lack of time for leisure, family, friends and personal needs as well as concerns about the professional future.

In this way, Carlotto et al. (2006), Dyrbye et al. (2010), Martinez et al. (2000) and Salanova, Schaufeli, Martinez and Breso (2010) emphasize that early detection of symptomatic significant levels of burnout can be an indicator of potential problems, both in school and professionally, enabling preventive interventions. Marôco and Tecedeiro (2009) reported that students when facing social and professional pressures, which they experience regarding the studies' financing and the relationships with teachers and peers, are highly likely to develop burnout. The occurrence of this syndrome can seriously limit both the psycho-social wellbeing and the academic performance of these students. Thus, for detection of burnout it is necessary to use reliable and valid measuring instruments that enable a reliable and valid diagnosis.

Thus, we carried out this study aiming at proposing and evaluating the reliability and validity of the Portuguese version of the Copenhagen Inventory adapted for students (CBI-S), as well as studying its transcultural stability in two samples from Brazil and Portugal.

\section{Method}

\section{Participants}

The participants were volunteer higher education students, enrolled in Brazilian and Portuguese institutions.
The invitation to for each institution to participate in this study was made by the researchers in person or via e-mail sent to the schools' direction. Participation was anonymous and no information that could be used to identify participants was requested.

\section{Study Variables}

To characterize the sample, sociodemographic information, such as age, sex, area of undergraduate course, type of institution, classes' shift, housing, studies' financing, use of medication due to studies and thought about quitting the course, was assessed.

To evaluate the Burnout Syndrome we used the Copenhagen Inventory (CBI) which was proposed by Kristensen et al. (2005) to the general population. Kristensen et al. (2005) report adequate reliability and validity of the $\mathrm{CBI}$ in different cultures, namely in Japan, Australia, China and New Zealand.

\section{Adaptation of the Instrument}

Since we did not find a Portuguese version of CBI in the literature, in this study we did translation and back translation from the original version of the CBI into Portuguese. To develop this instrument in the Portuguese language, adapted to the cultural context of both Brazil and Portugal, the translation of the CBI into Portuguese was made according to the spelling agreement (Ministério da Ciência, 2008), being adjusted for its application in university students. The adapted instrument was called by us the Copenhagen Burnout Inventory - Student Version (CBI-S).

To adequate the instrument to the students' context, when making the adaptation from the original format, the instrument was composed by the following dimensions: Personal Burnout (PB), Studies-related Burnout (SRB), Colleagues-related Burnout (CRB) and Teachers-related Burnout (TRB). It is important to highlight that, in our proposal (CBI-S), the questions regarding the third dimension were duplicated given that, for students, both relationships with peers and teachers can act as determinants of the burnout syndrome. The suitability of this duplication will be analyzed through face, content and construct related validities.

\section{Face Validity}

To assess the face related validity of the CBI-S, eight Psychology and English professionals evaluated the idiomatic, semantic, cultural and conceptual equivalence of the instrument. Once the experts came to a consensus, the final version was pre-tested in a group of 20 students to determine the misunderstanding index for each question.

\section{Content Validity}

To study the content validity of each item of CBI-S, 3 psychology professionals (judges) classified them into "essential", "useful, but non-essential" and "not neces- 
Campos, J. A. D. B., Carlotto, M. S. \& Marôco, J. (2013). Copenhagen Burnout Inventory - Student Version: Adaptation and Transcultural Validation for Portugal and Brazil.

sary”. We calculated the Content Validity Ratio (CVR), and to decide the significance of each item we used Lawshe (1975) proposal, adopting a significance level of $5 \%$.

\section{Procedures}

The questionnaires were available online for completion for 7 months (from May to November) on a website. Each web page hosted an instrument so that the respondent could view all items simultaneously. Non-responses to the items were allowed and the participants could return to verify and/or correct the answers to each inventory before its submission.

\section{Psychometric Qualities}

Sensibility. Measures of central tendency and shape were used to assess the psychometric sensitivity of each item. Items with absolute values of $\mathrm{Sk}>3$ and $\mathrm{Ku}>7$, were considered as having sensitivity problems (Kline, 1998).

\section{Construct Validity}

Factorial Validity. A confirmatory factor analysis (CFA) of the Portuguese version for students (CBI-S) was conducted to verify if the structure proposed by Kristensen et al. (2005) presented an adequate fit for this study's sample. As goodness of fit indices we used $\chi^{2} / d f$ (ratio chi-square and degrees of freedom), CFI (confirmatory fit index), GFI (goodness of fit index) e RMSEA (root mean square error of approximation). The adjustment of the model was considered good for CFI and GFI values above .9 and RMSEA values below .10 (Boomsma, 2000; Byrne, 2001; Marôco, 2010; McDonald \& Ho, 2002). The CFA analysis was perfomerd with $\mathrm{AMOS}^{\circledR} 18.0$.

\section{Items' Reduction}

The items that showed either negative factorial weights $(\lambda)$, or $\lambda$ lower than .5 were removed. Items that were redundant based on the modification indices calculated by Langrange multipliers (LM), as estimated by $\mathrm{AMOS}^{\circledR}$, were also removed; for this, the trajectories and/or correlations with LM>11 $(p<.001)$ were indicators of significant variation in the model's quality of adjustment if the items were to be removed and/or correlated with different dimensions from the ones originally proposed (Marôco, 2010).

\section{Factorial Invariance}

To assess the stability of the factor solution obtained, a cross-validation of the model was performed by comparing the goodness of fit observed in the sample with another independent sample coming from the same population (Hair, Black, Babin, Anderson, \& Tatham, 2005; Marôco, 2010). With that propose, the total sample was divided into three equal parts, with two parts being the "Test Sample" and one the "validation sample". The invariance test was conducted imposing equality restrictions to the factor weights from both samples, being the test statistics the difference between the model's $\chi^{2}$ with fixed factorial weights and the model with equal weights.

When the hypothesis of invariance of the factorial weights was accepted, an analysis of the covariance's invariance was performed between factors and the invariance of specific factors (residues; Kaplan, 2000). Afterwards, the same procedure was performed to assess the stability of the obtained factor solution by comparing the differences in $\chi^{2}$ between the models fitted to the Brazilian sample and the Portuguese sample.

\section{Convergent Validity}

Convergent validity was estimated by the Average Variance Extracted (AVE) and the Composite Reliability (CR; Fornell \& Larcker, 1981; Marôco, 2010) being considered adequate values of $A V E \geq .5$ and $C R \geq .7$ according to the proposal by Hair et al. (2005).

\section{Discriminant Validity}

To verify if the items that represent a factor were not correlated with some other factor (Marôco, 2010) we estimated the discriminant validity according to Fornell and Larcker's proposal (1981) as described in Marôco (2010): for two factors $i$ and $j$, if $A V E_{i}$ and $\operatorname{AV} E_{j} \geq \rho_{i j}{ }^{2}\left(\rho_{i j}{ }^{2}\right.$ : squared correlation between the factors $i$ and $j$ ) there is evidence of discriminant validity.

\section{Criterion Validity}

To estimate the validity associated to the criterion we calculated the concurrent validity and the divergent validity using Pearson's correlation analysis. For the former, the mean score of each CBI-S' dimension was correlated with that obtained in each dimension of the Maslach Burnout Inventory (MBI-SS); as for the divergent validity for the mean scores, CBI-S' dimensions were correlated with the Beck's Depression Inventory (BDI) score.

\section{Internal Consistency}

Internal consistency was assessed using the standardized Cronbach's alpha coefficient $(\alpha)$ for each dimension proposed on the inventories, and the stratified alpha coefficient for the total scale.

\section{Ethical Aspects}

The present study was approved by the Ethics Committee on Human Research of the Lutheran University of Brazil, Canoas/RS (protocol: 2010-188H).

\section{Results}

The Portuguese version of the Copenhagen Inventory for students (CBI-S), developed in the face validation process, is presented in Figure 1. 


\begin{tabular}{|ccccc|}
\hline Never & Rarely & Sometimes & Frequently & Always \\
1 & 2 & 3 & 4 & 5 \\
$0 \%$ of times & $25 \%$ of times & $50 \%$ of times & $75 \%$ of times & $100 \%$ of times \\
\hline
\end{tabular}

$\begin{array}{ccccc}\text { Never } & & & & \text { Always } \\ 1 & 2 & 3 & 4 & 5\end{array}$

\section{Personal Burnout}

Burnout pessoal

1. How often do you feel tired?

Com que freqüência se sente cansado?

2. How often are you physically exhausted?

Com que freqüência se sente fisicamente exausto?

3. How often are you emotionally exhausted?

Com que freqüência se sente emocionalmente exausto?

4. How often do you think: "I can't take it anymore"?

Com que freqüência pensa "Não agüento mais"?

5. How often do you feel worn out?

Com que freqüência se sente esgotado?

6. How often do you feel weak and susceptible to illness?

Com que freqüência se sente fraco e susceptível de adoecer?

Shedies related Burnout

Burnout relacionado aos estudos

7. Do you feel worn out at the end of the working day? Sente-se esgotado no final de um dia de Faculdade?

8. Are you exhausted in the morning at the thought of another day at work? Sente-se exausto logo pela manhã quando pensa em mais um dia na Faculdade?

9. Do you feel that every working hour is tiring for you? Sente que cada hora de aula/estudo é cansativa para você?

*10. Do you have enough energy for family and friends during leisure time? Tem tempo e energia para a família e amigos durante os tempos de lazer?

11. Is your studies emotionally exhausting? Os seus estudos são emocionalmente esgotantes?

12. Does your studies frustrate you? Sente-se frustrado com os seus estudos?

13. Do you feel burn out because of your studies? Sente-se exausto de forma prolongada com os seus estudos?

\section{Colleagues related Burnout}

Burnout relacionado aos colegas

14. Do you find it hard to work with colleagues? Você acha difícil trabalhar com seus colegas de estudo?

15. Does it drain your energy to work with colleagues? Sente que esgota sua energia quando trabalha com colegas?

16. Do you find it frustrating to work with colleagues? Acha frustrante trabalhar com colegas?

17. Do you feel that you give more than you get back when you work with colleagues? Sente que dá mais do que recebe quando trabalha com colegas?

18. Are you tired of working with colleagues? Está cansado de aturar os colegas?

19. Do you sometimes wonder how long you will be able to continue working with colleagues? Alguma vez se questiona quanto tempo mais conseguirá trabalhar com os colegas?

${ }^{* *}$ Teachers related Burnout

${ }^{* *}$ Burnout relacionado aos professores

20. Do you find it hard to work with teachers? Você acha difícil lidar com os professores?

21. Does it drain your energy to work with teachers?

Sente que esgota sua energia quando tem que lidar com os professores?

22. Do you find it frustrating to work with teachers? Acha frustrante lidar com os professores?

23. Do you feel that you give more than you get back when you work with teachers? Sente que dá mais do que recebe quando lida com professores?

24. Are you tired of working with teachers? Está cansado de lidar com os professores?

25. Do you sometimes wonder how long you will be able to continue working with teachers? Alguma vez se questiona quanto tempo mais conseguirá lidar com os professores?

Figure 1. Preliminary version in Portuguese of the Copenhagen Burnout Inventory Adapted for Students (CBI-S). Note. ${ }^{*}$ Item with a punctuation in e reversed order; **Dimension added to the original inventory. 
Campos, J. A. D. B., Carlotto, M. S. \& Marôco, J. (2013). Copenhagen Burnout Inventory - Student Version: Adaptation and Transcultural Validation for Portugal and Brazil.

Table 1

Content Validity Ratio of the Portuguese Version of the Copenhagen Burnout Inventory for Students (CBI-S)

\begin{tabular}{ccccc}
\hline CBI & Not necessary & Useful, but not essential & Essential & CVR \\
\hline C1 & - & 2 & 11 & .69 \\
C2 & 1 & 1 & 11 & .69 \\
C3 & - & 2 & 11 & .69 \\
C4 & - & - & 13 & 1.00 \\
C5 & 1 & 2 & 9 & $.50^{\mathrm{a}}$ \\
C6 & 1 & 6 & 6 & $-.08^{\mathrm{a}}$ \\
C7 & - & 1 & 12 & .85 \\
C8 & - & - & 13 & 1.00 \\
C9 & - & 4 & 9 & $.38^{\mathrm{a}}$ \\
C10 & 2 & 5 & 6 & $-.08^{\mathrm{a}}$ \\
C11 & 1 & 3 & 9 & $.38^{\mathrm{a}}$ \\
C12 & 1 & 4 & 8 & $.23^{\mathrm{a}}$ \\
C13 & 1 & 2 & 10 & .54 \\
C14 & 2 & 4 & 7 & $.08^{\mathrm{a}}$ \\
C15 & 1 & 3 & 9 & $.38^{\mathrm{a}}$ \\
C16 & 3 & 4 & 6 & $-.08^{\mathrm{a}}$ \\
C17 & 2 & 6 & 4 & $-.33^{\mathrm{a}}$ \\
C18 & 2 & 3 & 7 & $.17^{\mathrm{a}}$ \\
C19 & 1 & 3 & 8 & $.33^{\mathrm{a}}$ \\
C20 & 2 & 7 & 4 & $-.38^{\mathrm{a}}$ \\
C21 & 1 & 1 & 11 & .69 \\
C22 & 3 & 4 & 6 & $-.08^{\mathrm{a}}$ \\
C23 & 4 & 5 & 4 & $-.38^{\mathrm{a}}$ \\
C24 & - & 3 & 10 & .54 \\
C25 & 2 & 4 & 7 & $.08^{\mathrm{a}}$ \\
& & & &
\end{tabular}

Note. ${ }^{*} \mathrm{CVR}_{12 ; 0,05}=.56 ; \mathrm{CVR}_{13 ; 0,05}=.54 ;{ }^{\mathrm{a}}$ values below the significant minimum.

The pre-test showed that no item presented an incomprehension index $\geq .20$. The content validity ratio (CVR) may be observed in Table 1.

In the judge's opinion only 9 items are essential components of the CBI for the assessment of the Burnout Syndrome in students.

The instruments were completed by a total of 1052 Brazilian students and 612 Portuguese students. However, only 958 Brazilians (Response Rate - $R R=91.1 \%$ ) and 556 Portuguese $(\mathrm{RR}=90.9 \%)$ completed all the items and were included in this study. The mean age of the Brazilians was $23.1(S D=5.1)$ years and of the Portuguese $23.8(S D=7.6)$ years. The participants' sociodemographic data is presented in Table 2.

The summary measures of items that compose the CBI-S, to characterize the psychometric sensitivity of the Brazilian and Portuguese samples, are presented in Table 3.
All the items presented skewness and kurtosis' values close to the normal distribution $(\mathrm{Sk}=0, \mathrm{Ku}=0)$ in the different samples. Only item 25 were slightly leptokurtic in the Portuguese sample, but without compromising the psychometric sensitivity.

The Confirmatory Factor Analysis pointed to an adequate goodness of fit of CBI-S to this study's sample $\left(\chi^{2} / d f=5.473\right.$; CFI $=.928 ; \mathrm{GFI}=.889$; RMSEA $\left.=.067\right)$. However, the factor weights of the item 10 of the SRB dimension, and item 22 of the TRB dimension were below .5 , being that for item 22 the factor weight was negative. Thus, there was a refinement of t0he original model by removing these two items. We propose a reduced scale, with the dimensions SRB and TRB being composed by 6 and 5 items, respectively (Figure 2). 
Table 2

Determination [n (\%)] of Sociodemographic Variables Participating Students

\begin{tabular}{|c|c|c|c|}
\hline \multirow[b]{2}{*}{ Variable } & \multicolumn{3}{|c|}{ País } \\
\hline & Brazil & Portugal & Brazil and Portugal \\
\hline \multicolumn{4}{|l|}{ Sex } \\
\hline Female & $510(53.3)$ & $448(80.9)$ & $958(63.4)$ \\
\hline Male & $446(46.7)$ & $106(19.1)$ & $552(36.6)$ \\
\hline \multicolumn{4}{|l|}{ Course area } \\
\hline Biological sciences & $55(5.8)$ & $53(9.5)$ & $108(7.2)$ \\
\hline Exact sciences & $308(32.7)$ & - & $308(20.6)$ \\
\hline Social and Human sciences & $109(11.6)$ & $503(90.5)$ & $612(40.8)$ \\
\hline Health sciences & $471(49.9)$ & - & $471(31.4)$ \\
\hline \multicolumn{4}{|l|}{ Type of school } \\
\hline Private & $438(46.9)$ & $503(90.5)$ & $941(63.2)$ \\
\hline Public & $496(53.1)$ & $53(9.5)$ & $549(36.8)$ \\
\hline \multicolumn{4}{|l|}{ Course shift } \\
\hline Morning/Full-time & $409(44.2)$ & $225(45.3)$ & $634(44.5)$ \\
\hline Afternoon & $27(2.9)$ & $100(20.1)$ & 127(9.0) \\
\hline Night & $490(52.9)$ & 172(34.6) & $662(46.5)$ \\
\hline \multicolumn{4}{|l|}{ Year of the course } \\
\hline 1 & $211(22.0)$ & 25(4.6) & $236(15.7)$ \\
\hline 2 & $237(24.7)$ & $367(67.3)$ & $604(40.2)$ \\
\hline 3 & $272(28.4)$ & $73(13.4)$ & $345(23.0)$ \\
\hline 4 & 204(21.3) & $37(6.8)$ & $241(16.0)$ \\
\hline 5 & $34(3.6)$ & $43(7.9)$ & $77(5.1)$ \\
\hline \multicolumn{4}{|l|}{ Living conditions } \\
\hline Friends & 294(30.7) & 75(13.7) & $369(24.5)$ \\
\hline Family & $539(56.4)$ & $410(74.7)$ & $949(63.1)$ \\
\hline Alone & $123(12.9)$ & $64(11.7)$ & $187(12.4)$ \\
\hline \multicolumn{4}{|l|}{ Study's financing } \\
\hline Scholarship & 83(9.1) & $16(3.0)$ & $99(6.8)$ \\
\hline Family & $566(61.7)$ & $371(69.5)$ & $937(64.6)$ \\
\hline Own & $268(29.2)$ & $147(27.5)$ & $415(28.6)$ \\
\hline \multicolumn{4}{|l|}{ Medication intake due to studies } \\
\hline Never/Rarely & $605(63.6)$ & 427(77.7) & $1.030(68.7)$ \\
\hline Sometimes & 292(30.7) & $112(20.5)$ & $404(27.0)$ \\
\hline Frequently & $56(5.8)$ & $10(1.8)$ & $65(4.3)$ \\
\hline \multicolumn{4}{|l|}{ Thought about quitting the course } \\
\hline Never & $553(58.0)$ & $396(71.7)$ & $949(63.0)$ \\
\hline Sometimes & $340(35.6)$ & 132(23.9) & $472(31.3)$ \\
\hline Frequently & $61(6.4)$ & 24(4.4) & $85(5.6)$ \\
\hline
\end{tabular}


Campos, J. A. D. B., Carlotto, M. S. \& Marôco, J. (2013). Copenhagen Burnout Inventory - Student Version: Adaptation and Transcultural Validation for Portugal and Brazil.

Table 3

Psychometric Sensitivity of the Items Composing the Portuguese Version of the Copenhagen Burnout Inventory for Brazilian (BR) and Portuguese (PT) Students (CBI-S)

\begin{tabular}{|c|c|c|c|c|c|c|c|c|c|c|c|c|}
\hline \multirow[b]{2}{*}{ CBI-S } & \multicolumn{2}{|c|}{ Mean } & \multicolumn{2}{|c|}{ Median } & \multicolumn{2}{|c|}{ Mode } & \multicolumn{2}{|c|}{$D P$} & \multicolumn{2}{|c|}{ Kurtoses } & \multicolumn{2}{|c|}{ Skewness } \\
\hline & BR & PT & $\mathrm{BR}$ & $\mathrm{PT}$ & $\mathrm{BR}$ & $\mathrm{PT}$ & $\mathrm{BR}$ & PT & $\mathrm{BR}$ & PT & $\mathrm{BR}$ & PT \\
\hline $\mathrm{C} 1$ & 3.33 & 3.16 & 3 & 3 & 3 & 3 & .89 & .74 & -.45 & -.19 & .01 & .17 \\
\hline $\mathrm{C} 2$ & 3.08 & 2.79 & 3 & 3 & 3 & 2 & .98 & .89 & -.60 & -.43 & .18 & .32 \\
\hline $\mathrm{C} 3$ & 3.05 & 2.81 & 3 & 3 & 3 & 3 & 1.02 & .95 & -.64 & -.41 & .14 & .25 \\
\hline $\mathrm{C} 4$ & 2.68 & 2.24 & 3 & 2 & 2 & 2 & 1.15 & 1.00 & -.71 & -.21 & .35 & .61 \\
\hline $\mathrm{C} 5$ & 2.83 & 2.54 & 3 & 2 & 2 & 2 & 1.05 & .92 & -.51 & -.26 & .35 & .37 \\
\hline C6 & 2.22 & 2.21 & 2 & 2 & 2 & 2 & 1.11 & .89 & .01 & -.04 & .81 & .54 \\
\hline C7 & 3.15 & 2.87 & 3 & 3 & 3 & 3 & 1.07 & .95 & -.70 & -.42 & .04 & .11 \\
\hline $\mathrm{C} 8$ & 2.55 & 2.23 & 2 & 2 & 2 & 2 & 1.11 & .99 & -.46 & -.19 & .48 & .60 \\
\hline C9 & 2.61 & 2.36 & 2 & 2 & 2 & 2 & 1.01 & .88 & -.31 & .12 & .42 & .45 \\
\hline $\mathrm{C} 10$ & 2.52 & 3.59 & 2 & 4 & 2 & 4 & 1.18 & .98 & -.87 & -.52 & .31 & -.35 \\
\hline C11 & 2.76 & 2.52 & 3 & 2 & 3 & 2 & 1.06 & .94 & -.44 & -.10 & .30 & .37 \\
\hline $\mathrm{C} 12$ & 2.27 & 2.03 & 2 & 2 & 2 & 2 & 1.09 & .97 & -.23 & .13 & .64 & .77 \\
\hline $\mathrm{C} 13$ & 2.48 & 2.20 & 2 & 2 & 2 & 2 & 1.07 & .97 & -.37 & -.29 & .47 & .51 \\
\hline $\mathrm{C} 14$ & 2.32 & 2.13 & 2 & 2 & 2 & 2 & 1.10 & .97 & -.16 & .29 & .67 & .76 \\
\hline $\mathrm{C} 15$ & 2.24 & 2.17 & 2 & 2 & 2 & 2 & 1.09 & .95 & -.13 & .55 & .72 & .78 \\
\hline $\mathrm{C} 16$ & 2.02 & 1.83 & 2 & 2 & 1 & 1 & 1.09 & .97 & .23 & .70 & .98 & 1.09 \\
\hline $\mathrm{C} 17$ & 2.48 & 2.41 & 2 & 2 & 2 & 2 & 1.18 & 1.05 & -.72 & -.64 & .41 & .36 \\
\hline $\mathrm{C} 18$ & 2.00 & 1.83 & 2 & 2 & 1 & 1 & 1.12 & .95 & .24 & .94 & 1.01 & 1.13 \\
\hline C19 & 1.98 & 1.70 & 2 & 1 & 1 & 1 & 1.18 & .94 & .27 & 1.57 & 1.11 & 1.39 \\
\hline $\mathrm{C} 20$ & 2.35 & 1.77 & 2 & 2 & 2 & 2 & 1.02 & .78 & -.10 & .98 & .55 & .91 \\
\hline $\mathrm{C} 21$ & 2.19 & 1.50 & 2 & 1 & 2 & 1 & 1.06 & .69 & .23 & 1.94 & .83 & 1.36 \\
\hline C22 & 3.85 & 4.41 & 3 & 6 & 2 & 6 & 1.72 & 1.86 & -1.69 & -1.78 & .24 & -.38 \\
\hline $\mathrm{C} 23$ & 2.10 & 1.69 & 2 & 2 & 1 & 1 & 1.07 & .82 & .23 & .61 & .87 & 1.05 \\
\hline $\mathrm{C} 24$ & 2.08 & 1.53 & 2 & 1 & 1 & 1 & 1.12 & .74 & .10 & 1.98 & .93 & 1.39 \\
\hline $\mathrm{C} 25$ & 1.95 & 1.40 & 2 & 1 & 1 & 1 & 1.12 & .66 & .39 & 4.28 & 1.09 & 1.89 \\
\hline
\end{tabular}

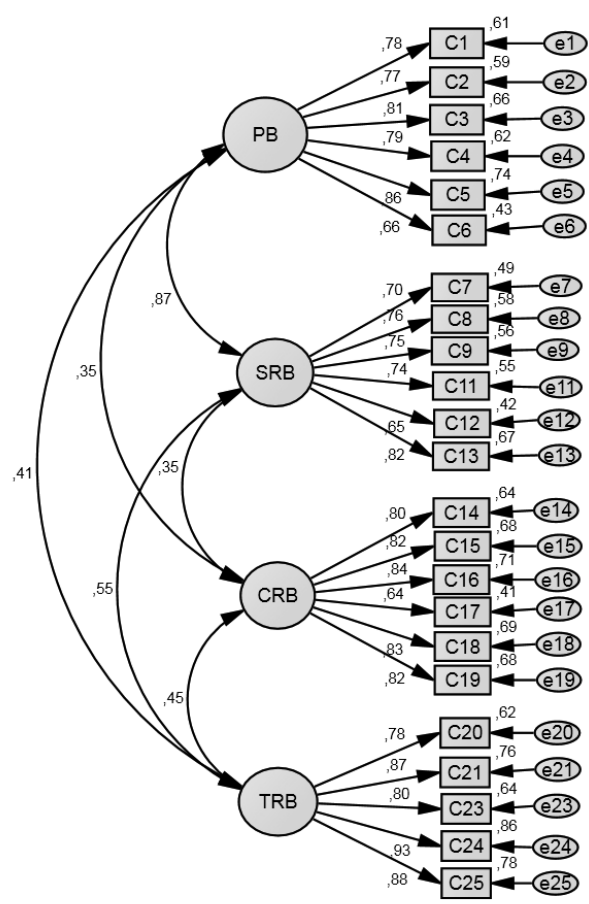

Figure 2. Confirmatory Factor Analysis of the Copenhagen Burnout Inventory for Students Adapted into Portuguese (CBI-S; $\chi^{2} /$ $d f=6.094 ; \mathrm{CFI}=.931 ; \mathrm{GFI}=.889$; RMSEA=.071; Global Sample Brazil-Portugal). 
The values shown in the Figure 2 are the standardized estimates of the covariance between the factors and factor weights. We further present the explained variance of each item.

We observed that the factor model has appropriate goodness of fit indices. All items of the scale (CBI-S) showed factorial weights $(\lambda) \geq .5$ and adequate individual reliability $\left(R^{2} \geq .25\right)$. We also observed a moderate to strong correlation between factors $(r=.35-.87)$.

In the external validation of the refined factorial structure, we analyzed the invariance between in the test sample and the validation sample Evaluation simultaneously in both samples revealed levels of appropriate goodness of fit $\left(\chi^{2} / d f=4.602 ; \mathrm{CFI}=.928 ; \mathrm{GFI}=.876\right.$; $\left.\mathrm{RMSEA}=.049\right)$. The fit of the structural model and the covariance between factors, of the two samples, revealed no significant differences between them $\left[\lambda: \chi^{2}(19)_{d i f}=17.279, p=.571\right.$; Cov: $\left.\chi^{2}(10)_{d i f}=11.197, p=.342\right]$. These observations point to the invariance of the model in two independent samples, confirming the stability of the factor structure proposed in this adaptation and validation study.

An adequate convergent validity (PB: $\mathrm{VEM}=.609$, $\mathrm{CC}=.903$; $\mathrm{SRB}: \mathrm{VEM}=.545, \mathrm{CC}=.877$; $\mathrm{CRB}: \mathrm{VEM}=.637$, $\mathrm{CC}=.913$; TRB: $\mathrm{VEM}=.729, \mathrm{CC}=.931)$ and discriminant validity (PB: $r^{2}=.104-.603$; SRB: $r^{2}=.091-.603$; CRB: $r^{2}=.091-.170$; TRB: $\left.r^{2}=.140-.249\right)$ were found. The discriminant validity was hampered in the SRB dimension only due to its high correlation with PB. Internal consistency estimated by Cronbach's alpha, was excellent for all CBI-S dimensions $\left(\alpha_{\mathrm{BP}}=.901 ; \alpha_{\mathrm{BRE}}=.875 ; \alpha_{\mathrm{BRC}}=.910\right.$; $\left.\alpha_{\mathrm{BRP}}=.931\right)$ and for the total scale $(\alpha=.957)$.

The correlational analysis between Copenhagen Inventory for Students (CBI-S) and the Maslach Burnout Inventory - Student Survey (MBI-SS) as well as the Beck Depression Inventory (BDI) are presented in Table 4.

Table 4

Correlation Matrix between the Copenhagen Burnout Inventory for Students (CBI-S) and the Maslach Burnout Inventory (MBI-SS) and the Beck Depression Inventory (BDI)

\begin{tabular}{|c|c|c|c|c|c|c|c|c|c|}
\hline & & \multicolumn{4}{|c|}{ CBI-S* } & \multicolumn{3}{|c|}{ MBI-SS* } & \multirow[t]{2}{*}{ BDI } \\
\hline & & PB & SRB & CRB & TRB & Ex. & Cyn. & Prof. Ef. & \\
\hline \multirow[t]{4}{*}{ CBI-S } & BP & 1.00 & - & - & - & - & - & - & - \\
\hline & SRB & .78 & 1.00 & - & - & - & - & - & - \\
\hline & CRB & .32 & .30 & 1.00 & - & - & - & - & - \\
\hline & TRB & .37 & .50 & .41 & 1.00 & - & - & - & - \\
\hline \multirow[t]{3}{*}{ MBI-SS } & Ex. & .67 & .74 & .25 & .41 & 1.00 & - & - & - \\
\hline & Cyn. & .46 & .59 & .21 & .46 & .58 & 1.00 & - & - \\
\hline & Prof. Ef. & -.24 & -.35 & -.06 & -.21 & -.25 & -.38 & 1.00 & - \\
\hline BDI & & .45 & .49 & .39 & .60 & .44 & .44 & -.08 & 1.00 \\
\hline
\end{tabular}

Note. *CBI-S: PB: Personal Burnout, SRB: Studies-related Burnout, CRB: Colleagues-related Burnout, TRB: Teachers-related Burnout; MBI-SS: Ex.: Emotional Exhaustion, Cyn.: Cynicism, Prof. Ef.: Professional Efficacy.

We observed strong correlations between the CBI dimensions PB and SRB with the MBI-SS dimension Emotional Exhaustion; moderate correlations were found between PB, SBR and TRB with the MBI-SS dimension Cynicism, indicating adequate concurrent validity of the CBI-S. On the other hand, the moderate to strong correlation between the CBI-S and BDI denote the existence of an approximation between the theoretical constructs of both instruments, in this sample (Exhaustion and Depression, respectively, for CBI-S and BDI) which makes the assessment of the divergent validity of the scale more difficult.

In evaluating the adjustment simultaneously in Brazilian and Portuguese samples we can observe appropriate goodness of fit indices $\left(\chi^{2} / d f=5.459\right.$; CFI: $=.907$; $\mathrm{GFI}=.858$; RMSEA $=.054)$ however, there was no crosscultural invariance of the models $\left[\lambda: \chi^{2}(19)_{d i f}=43.744\right.$, $p=.001$; Cov: $\chi^{2}(29)_{d i f}=204,251, p<.001$; Residuals:, $\left.\chi^{2}(52)_{d i f}=510,739, p<.001\right]$. Figure 3 shows separately the factor models of both samples.

Finally, there was an absence of cross-cultural equivalence between countries. However, we would like to highlight the proximity of the values of the items' factor weights and the correlations between the CBI-S scales in the different samples. The large sample sizes used for both countries may have exacerbated the statistical significances of the small differences observed between the factor weights.

\section{Discussion}

The present study indicates that the psychometric properties of the CBI-S are satisfactory, being that, to the best of our knowledge, this is the first study that evaluates the reliability and validity of the instrument in a students' sample. These results support what Kristensen et al. (2005) 
Campos, J. A. D. B., Carlotto, M. S. \& Marôco, J. (2013). Copenhagen Burnout Inventory - Student Version: Adaptation and Transcultural Validation for Portugal and Brazil.

\section{A) Brazil}

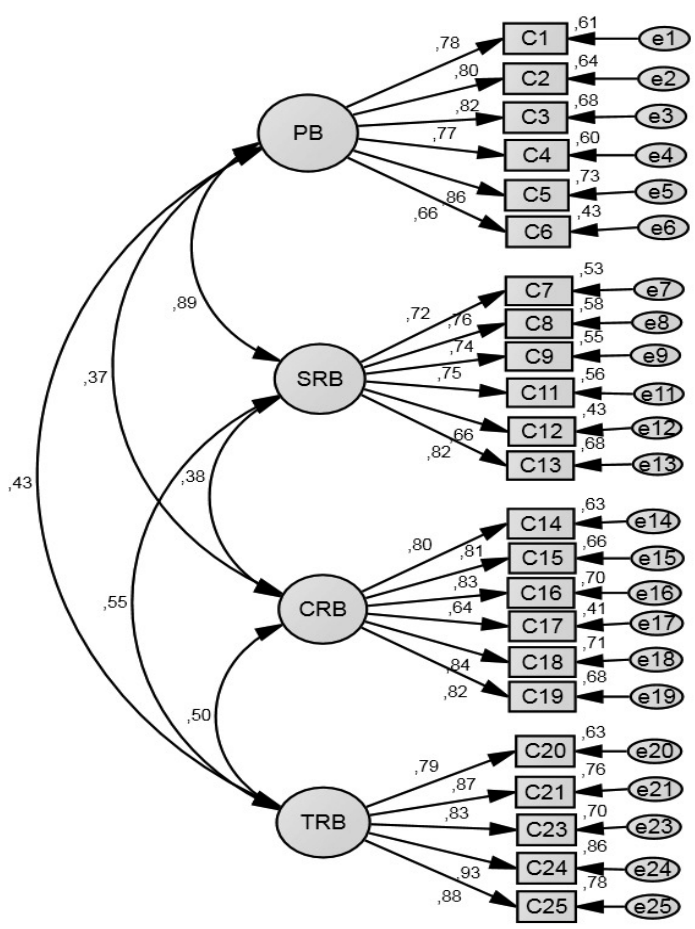

B) Portugal

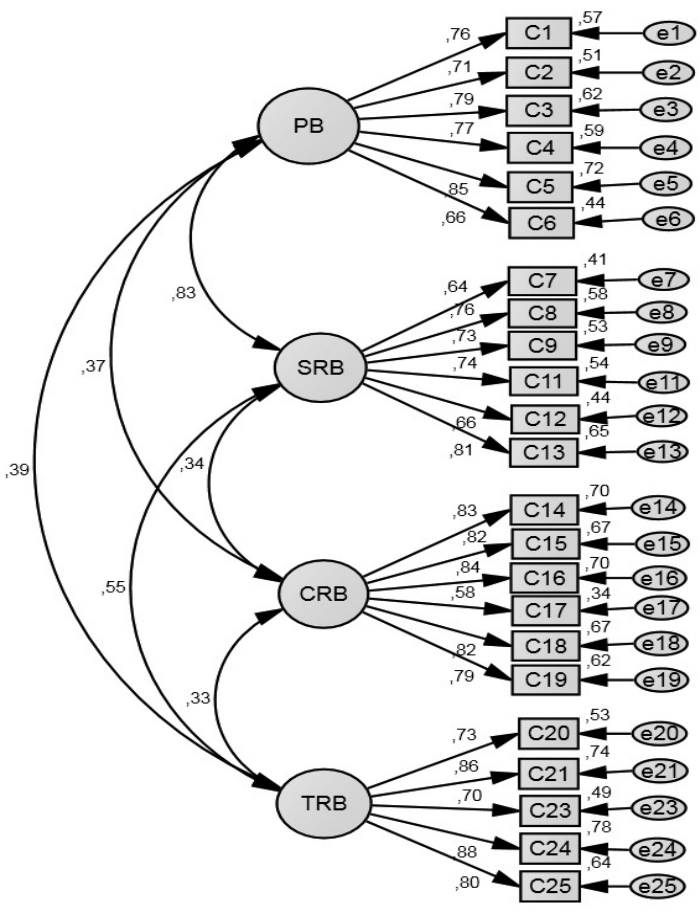

Figure 3. Confirmatory Factor Analysis of the Copenhagen Burnout Inventory for Students adapted into Portuguese (CBI-S) for a Brazilian Sample (A) $\left[\chi^{2} / d f=6.504 ; \mathrm{CFI}=.924 ; \mathrm{GFI}=.876 ; \mathrm{RMSEA}=.076\right]$ and a Portuguese Sample $(\mathrm{B})\left[\chi^{2} / d f=3.401 ; \mathrm{CFI}=.931\right.$; $\mathrm{GFI}=.887$; RMSEA $=.066]$.

suggest when they mention that the CBI can be used in broader contexts than those originally proposed.

Despite the fact that the expert panel (Table 1) pointed out that only 9 items were essential components of the CBI for the assessment of Burnout Syndrome in students, in the Confirmatory Factor Analysis (CFA) most items showed adequate factorial weights. It is worth noting that two items deemed as unnecessary by the specialists panel had both $\lambda<.50$ and a low CVR.

Item $10(\mathrm{C} 10)$ showed a low negative factor weight, which may have occurred because it is the only one with a reverse formulation. Given that all the items had the same response direction, a stereotype might have been created, i.e. a pattern where participants may have answered without realizing that item 10's response scale was reversed. This same behavior was observed by Yeh et al. (2007) when assessing the psychometric properties of the Chinese version of the CBI.

Regarding item 22 (C22), it is interesting to note that this question is part of the dimension "teachers-related burnout" and was doubled in the dimension "colleaguesrelated burnout" and despite this it was the only with $\lambda<.50$. This may be due to differences between the relationships with colleagues and with teachers, being the first a symmetric relationship while the second is an asymmetric relationship, and burnout may not be equally applicable to both situations.
Regarding internal consistency, the high values found in the subscales of the CBI-S are in agreement with the data presented in previously published reports (Kristensen et al., 2005; Milfont et al., 2008; Yeh et al., 2007).

The confirmatory factor analysis indicated an adequate fit of the CBI-S tri-factorial model (Figures 2 and 3 ) confirming the findings of Milfont et al. (2008) when the CBI was applied to a sample of high school teachers in New Zealand.

Significant correlations were observed between the four CBI-S dimensions (Figures 2 and 3) indicating a considerable dependence between the scales. These data support the combination of the inventory's items for the computation of the overall burnout score. The strong correlation observed between " personal burnout" and "studies-related to burnout" was also reported by Yeh et al. (2007). In assessing the concurrent validity of the CBI$\mathrm{S}$, the lowest correlation values were observed in the MBISS dimension "Professional Efficacy", which was to be expected since, as in the theoretical conception of the MBI (Maslach \& Jackson, 1981) this is the factor that has a lower correlation with the others (Exhaustion and Cynicism).

In the analysis of invariance in the global sample we observed stability of the model, however, the comparison of this finding with other studies is hampered given that we did not find in the literature any studies that applied 
this method of analysis when assessing the psychometric properties of the CBI.

The moderate correlation found between the CBI-SS and the BDI (Table 4) may have occurred because, despite the fact that Burnout and depression are distinct concepts, they are often associated (Bakker, Schaufeli, Demerouti, Janssen, \& Van Der Hulst, 2000; Brenninkmeyer, Yperen, \& Buunk, 2001; Iacovides, Fountoulakis, Moysidou, \& Ierodiakonou, 1999). The meta-analysis conducted by Glass and McKnight (1996) highlight that, despite the fact that the two constructs present a shared variance of approximately $20 \%$, that does not mean there is isomorphism between concepts.

Comparing the factor structure obtained for Brazil and Portugal, we noted a lack of invariance of the model, which compromises the transcultural stability of the CBI$\mathrm{S}$. However, one must pay attention to the similarity between the factor structures presented (Brazil and Portugal) ensuring that the proposed model can be used in both countries. Only for item 23 was the difference observed in the factor weight $(>.10)$ statistically significant $(p<.05)$. The rejection of invariance can be related to the size of the sample used, given that in large samples even small differences can be detected as significant, or with sociodemographic differences between the samples (Table 2), or even with the high sensitivity of the analysis method used.

Given the adequate psychometric properties of the CBIS, we agree with Yeh et al. (2007) when they state that the greatest advantage of the $\mathrm{CBI}$ is that it exclusively assesses the state of fatigue/exhaustion not mistaking the experiences of burnout with other components, such as coping strategies or consequences of the syndrome. This preservation of the central concept of burnout can facilitate the identification of the relation between the syndrome and causal factors which may consequently contribute to the understanding of the syndrome.

The results presented should be considered in light of some limitations, such as the fact that this was a crosssectional study with samples from two countries (Brazil and Portugal) that had different socio-demographic characteristics (Table 2). Despite these limitations, we highlight the large size of the sample used and the analysis of invariance in independent populations, which, as far as we know, has not been previously reported. Also noteworthy was the fact that, despite the CBI already having a version in eight different languages (English, Japanese, Mandarin, Catalan, Swedish, Finnish, French and Slovenian) and having been tested on over 15 different occupational groups (Kristensen et al., 2005; Milfont et al., 2008), this is the first study that presents the Portuguese version of the instrument applied to a sample of college students.

The consistency of our findings with those reported in the literature, and the results of this study, attest to the reliability and validity of the CBI-S and support the recommendation of its use for the screening of Burnout Syndrome in students.

\section{Conclusion}

Due to the implications that the burnout syndrome presents for the physical and psychological well-being, as well as the academic performance of college students, it should be a concern to all professionals, particularly to teaching, health and psychological counseling professionals. In this perspective, the existence of measurement and diagnostic instruments adequately calibrated for the target population is a necessity. Our study contributes to the evaluation of the psychometric properties of the CBI$\mathrm{S}$ for the population of university students from Brazil and Portugal. The results indicate that the Portuguese version of the inventory for students is a good tool for assessing the occurrence of the syndrome and, thus, a useful tool for professionals working in health and psychological evaluation. Additionally, our results indicate that the Portuguese version of the Copenhagen Inventory for students (CBI-S) showed adequate reliability and validity. Despite the fact that its factor structure was not invariant between the Brazilian and Portuguese samples, the fit of the factor model was adequate for the two samples enabling the development of research in both countries with larger populations.

\section{References}

Bakker, A. B., Schaufeli, W. B., Demerouti, E., Janssen, P. P. M., \& Van Der Hulst, R. (2000). Using equity theory to examine the difference between burnout and depression. Anxiety, Stress \& Coping, 13(3), 247-268.

Balogun, J. A., Helgemoe, S., Pellegrini, E., \& Hoeberlein, T. (1995). Test-retest reliability of a psychometric instrument designed to measure physical therapy students' burnout. Perceptual \& Motor Skills, 81(2), 667-672.

Boomsma, A. (2000). Reporting analyses of covariance structures. Structural Equation Modeling-a Multidisciplinary Journal, 7(3), 461-483.

Brenninkmeyer, V., Yperen, N. W. V., \& Buunk, B. P. (2001). Burnout and depression are not identical twins: Is decline of superiority a distinguishing feature? Personality and Individual Differences, 30(5), 873-880.

Byrne, B. M. (2001). Structural equation modeling with Amos: Basic concepts, applications and programming. Mahwah, NJ: Lawrence Erlbaum.

Carlotto, M. S., Nakamura, A. P., \& Camara, S. G. (2006). Síndrome de Burnout em estudantes universitários da área da saúde. Psico-USF, 37(1), 57-62.

Demerouti, E., Bakker, A. B., Nachreiner, F., \& Schaufeli, W. B. (2001). The job demands-resources model of burnout. Journal of Applied Psychology, 86(3), 499-512.

Demerouti, E., Bakker, A. B., Vardakou, I., \& Kantas, A. (2003). The convergent validity of two burnout instruments - A multitrait-multimethod analysis. European Journal of Psychological Assessment, 19(1), 12-23. doi: 10.1027//10155759.19.1.12

Doty, D. H., \& Glick, W. H. (1998). Common methods bias: Does common methods variance really bias results? Organizational Research Methods, 1(4), 374-406. 
Campos, J. A. D. B., Carlotto, M. S. \& Marôco, J. (2013). Copenhagen Burnout Inventory - Student Version: Adaptation and Transcultural Validation for Portugal and Brazil.

Dyrbye, L. N., Thomas, M. R., Power, D. V., Durning, S., Moutier, C., Massie, F. S., Jr., et al. (2010). Burnout and serious thoughts of dropping out of medical school: A multiinstitutional study. Academic Medicine, 85(1), 94-102. doi: 10.1097/ACM.0b013e3181c46aad

Fornell, C., \& Larcker, D. F. (1981). Evaluating Structural Equation Models with unobservable variables and measurement error. Journal of Marketing Research, 18(1), 39-50.

Garden, A. M. (1987). Despersonalization: A valid measure of burnout? Human Relations, 40, 545-560.

Glass, D. C., \& McKnight, J. D. (1996). Perceived control, depressive symptomatology, and professional burnout: A review of the evidence. Psychology \& Health, 11(1), 23-48.

Hair, J. F., Black, W. C., Babin, B., Anderson, R. E., \& Tatham, R. L. (2005). Multivariate data analysis ( $6^{\text {th }} \mathrm{ed}$.). Upper Saddle River, NJ: Pearson.

Iacovides, A., Fountoulakis, K. N., Moysidou, C., \& Ierodiakonou, C. (1999). Burnout in nursing staff: Is there a relationship between depression and burnout? International Journal of Psychiatry in Medicine, 29(4), 421-433.

Kaplan, D. (2000). Structural equation modeling: Foundations and extensions. Thousand Oaks, CA: Sage.

Kline, R. B. (1998). Principles and practice of structural equation modeling. New York: The Guilford Press.

Kristensen, T. S., Borritz, M., Villadsen, E., \& Christensen, K. B. (2005). The Copenhagen Burnout Inventory: A new tool for the assessment of burnout. Work and Stress, 19(3), 192207. doi: 10.1080/02678370500297720

Lawshe, C. H. (1975). A quantitative approach to content validity. Personnel Psychology, 28(4), 563-575.

Marôco, J. (2010). Análise de equações estruturais. Lisboa, Portugal: ReportNumber.

Marôco, J., \& Tecedeiro, M. (2009). Inventário de Burnout de Maslach para estudantes portugueses. Psicologia, Saúde \& Doenças 10(2), 227-235.

Marôco, J., Tecedeiro, M., Martins, P., \& Meireles, A. (2008). Estrutura fatorial de segunda ordem da Escala de Burnout de Malasch para estudantes numa amostra portuguesa. Análise Psicológica, 26(4), 639-649.

Martinez, I. M. M., Pinto, A. M., \& Silva, A. L. (2000). Burnout em estudantes do ensino superior. Revista Portuguesa de Psicologia, 35, 151-167.

Maslach, C., \& Jackson, S. E. (1981). The Measurement of Experienced Burnout. Journal of Occupational Behaviour, 2(2), 99-113.

Maslach, C., Schaufeli, W. B., \& Leiter, M. P. (2001). Job burnout. Annual Review of Psychology, 52, 397-422. doi: 10.1146/annurev.psych.52.1.39752/1/397.

McDonald, R. P., \& Ho, M. H. R. (2002). Principles and practice in reporting structural equation analyses. Psychological Methods, 7(1), 64-82. doi: 10.1037//1082-989x.7.1.64.

Milfont, T. L., Denny, S., Ameratunga, S., Robinson, E., \& Merry, S. (2008). Burnout and wellbeing: Testing the Copenhagen Burnout Inventory in New Zealand teachers. Social Indicators Research, 89(1), 169-177. doi: 10.1007/ s11205-007-9229-9.

Ministério da Ciência. (2008). Acordo ortográfico de 1990. Retrieved October 27, 2008, from http://www.portaldalinguaportuguesa.org

Nogueira-Martins, M. C. F. (2001). Humanização das relações assistenciais: A formação do profissional da saúde. São Paulo, SP: Casa do Psicólogo.
Salanova, M., Schaufeli, W., Martinez, I., \& Breso, E. (2010) How obstacles and facilitators predict academic performance: The mediating role of study burnout and engagement. Anxiety Stress and Coping, 23(1), 53-70. doi: 10.1080/ 10615800802609965

Schaufeli, W. B., Leiter, M. P., \& Maslach, C. (2009). Burnout: 35 years of research and practice. The Career Development International, 14(3), 204-220.

Schaufeli, W. B., Martinez, I. M., Pinto, A. M., Salanova, M. \& Bakker, A. B. (2002). Burnout and engagement in university students - A cross-national study. Journal of CrossCultural Psychology, 33(5), 464-481.

Yeh, W. Y., Cheng, Y., Chen, C. J., Hu, P. Y., \& Kristensen, T. S. (2007). Psychometric properties of the Chinese version of Copenhagen burnout inventory among employees in two companies in Taiwan. International Journal of Behavioral Medicine, 14(3), 126-133. 